\title{
PENGARUH MODEL PEROLEHAN KONSEP DENGAN METODE DEMONSTRASI TERHADAP PENGUASAAN KONSEP FISIKA SISWA SMA
}

\author{
Atikatun Hulwani*, Susilawati, Kosim \\ Program Studi Pendidikan Fisika, Universitas Mataram \\ *Email: atika.hulwani@gmail.com
}

DOI: http://dx.doi.org/10.29303/jpft.v5i2.1377

\begin{abstract}
This study aims to analyze the effect of the concept attainment model with the demonstration method on the mastery of student physical concepts. This type of research is a quasi-experimental with pre-test and post-test control group design. The population in this study were all students of class XI MIPA in one of the state high schools in West Lombok. The sampling technique in this study used a purposive sampling technique, so that the sample used in the study was class XI MIPA 3 as an experimental class and class XI MIPA 6 as a control class. The instrument used in this study was in the form of multiple choice questions totaling 21 items. The pre-test results show that the average value of the experimental class is 37,3 and the control class is 35,9. Data analysis techniques using t-test with pre-test and post-test, so that the results of the hypothesis test conducted at the final test obtained $t$ count of 2,250 and t-table of 2,012. Because $t$-count is greater than $t$-table, it can be concluded that $H_{0}$ is rejected, it means that the concept attainment model with the demonstration method affects the mastery of the physics concepts of high school students.
\end{abstract}

Keywords: Concept attainment; demonstration method; concept mastery; physics

\section{PENDAHULUAN}

Kurikulum yang diterapkan dalam dunia pendidikan formal (sekolah) saat ini adalah kurikulum 2013 (K13). Adapun tema pengembangan K13 yaitu dapat menghasilkan insan Indonesia yang produktif, kreatif, inovatif, efektif melalui penguatan sikap, keterampilan dan pengetahuan yang terintegritas. Pada kurikulum ini, siswa dituntut untuk lebih aktif dalam belajar sementara peran guru adalah membimbing siswa tanpa harus mendominasi kelas seutuhnya (Kemdikbud, 2013).

Hal lain yang menjadi alasan dikembangkannya K13 saat ini adalah untuk mengatasi permasalahan yang sering terjadi pada proses pembelajaran termasuk pada mata pelajaran fisika. Fisika merupakan bagian dari mata pelajaran ilmu pengetahuan alam, yaitu ilmu hasil dari kegiatan manusia yang berupa pengetahuan, gagasan dan konsep yang tersusun dari kejadian alam sekitar yang diproleh berdasarkan pengalaman melalui proses ilmiah (Sugiono, 2002).
Berdasarkan hasil pengamatan pada suatu proses pembelajaran fisika di salah satu SMA Negeri yang ada di Lombok Barat, tampak bahwa motivasi siswa dalam mengikuti pelajaran perlu mendapatkan perhatian. Hal ini terlihat dari antusiasme, kesadaran dan kemauan siswa untuk bertanya sebagai upaya dalam memahami materi masih sangat rendah. Perhatian siswa dalam mengikuti pembelajaran kurang terkonsentrasi dimana siswa kurang berani mengutarakan idenya saat guru mengajukan pertanyaan. Permasalahan dalam proses pembelajaran dapat menyebabkan timbulnya masalah baru dalam dunia pendidikan, salah satunya adalah kemampuan siswa dalam memahami pelajaran menjadi rendah sehingga siswa mengalami kesulitan dalam menguasai konsep-konsep yang terkandung dalam fisika.

Sebagaimana diketahui, hasil belajar fisika dapat diukur dari penguasaan konsep fisika siswa seperti yang diungkapkan oleh Arianti et al. (2016) dalam penelitiannya bahwa penguasaan konsep fisika merupakan 
salah satu aspek yang sangat penting dalam mengukur hasil belajar siswa sehingga perlu untuk selalu ditingkatkan. Sementara Tuqalby et al. (2017) mengungkapkan bahwa penguasaan konsep merupakan salah satu aspek yang dapat membantu siswa dalam menyelesaikan suatu masalah atau persoalan dalam pembelajaran.

Beberapa faktor yang dapat menyebabkan siswa mengalami kesulitan dalam menguasai konsep-konsep fisika diungkapkan oleh Yulianci et al. (2017) dalam penelitiannya yaitu proses pembelajaran fisika didominasi oleh penggunaan persamaan-persamaan tanpa menjelaskan konsep yang terkandung di dalamnya sehingga siswa kurang dapat memaknai pembelajaran serta menyebabkan pemahaman siswa terhadap materi fisika sangat rendah. Oktaviani et al. (2018) juga berpendapat bahwa guru-guru di sekolah dalam mengajar fisika lebih memfokuskan pada hasil akhir daripada proses pembelajarannya sehingga menyebabkan rendahnya penguasaan konsep fisika yang dimiliki siswa.

Masalah rendahnya penguasaan konsep yang dimiliki oleh siswa tentu memerlukan solusi dalam pemecahannya. Salah satu cara yang dapat dilakukan untuk mengatasai masalah tersebut adalah perlu dilakukannya pengkajian lanjutan tentang alternatif pembelajaran yang dapat memfasilitasi proses terjadinya latihan berpikir untuk mengembangkan konsep fisika pada siswa. Salah satu model pembelajaran yang dapat dijadikan sebagai alternatif untuk meningkatkan kemampuan siswa dalam menguasai konsep-konsep fisika yaitu model perolehan konsep.

Model perolehan konsep menurut Fadilah et al. (2016) dalam penelitiannya adalah suatu proses mencari dan mendaftar sifat-sifat yang dapat digunakan untuk membedakan contoh-contoh yang tepat (contoh positif) dengan contoh-contoh yang tidak tepat (contoh negatif) dari berbagai kategori dengan tujuan untuk mendefinisikan konsep yang diharapkan. Selain itu, hasil penelitian yang dilakukan oleh Christiani et al. (2017) mengungkapkan bahwa respon siswa pada materi tekanan zat cair setelah digunakan model perolehan konsep adalah sangat baik. Hal ini ditunjukkan pada hasil angket respon siswa yang telah disebarkan pada 35 siswa kelas VIII-2 di SMP Negeri 5 Sidoarjo bahwa sebanyak $86,39 \%$ menyatakan respon positif terhadap model perolehan konsep. Alasan lainnya yang mendasari peneliti dalam memilih model perolehan konsep adalah dikarenakan model ini tidak hanya menuntut kemampuan guru dalam membimbing siswa tetapi juga berpotensi untuk mengaktifkan siswa sebagaimana yang dikemukakan oleh Yahya et al. (2015) dalam penelitiannya membuktikan bahwa aktivitas belajar siswa dengan menggunakan model perolehan konsep disertai teknik concept maping tergolong sangat aktif dengan skor rata-rata $83,9 \%$.

Dalam pembelajaran, penerapan model akan berjalan maksimal apabila disertai dengan penggunaan metode pembelajaran yang baik, menarik dan relavan dengan model tersebut. Metode pembelajaran yang dapat diaplikasikan pada model perolehan konsep adalah metode pembelajaran yang dapat memfasilitasi siswa dalam memproleh konsep, salah satunya yaitu metode demonstrasi. Menurut Syaiful (2008), metode demonstrasi adalah suatu metode pembelajaran dengan mempertunjukkan tentang proses terjadinya suatu peristiwa atau benda sampai pada penampilan tingkah laku yang dicontohkan agar dapat diketahui dan dipahami oleh siswa secara nyata atau tiruannya. Lebih jauh Syaiful (2008) juga mengemukakan bahwa siswa berkesempatan mengembangkan kemampuan mengamati segala peristiwa dan benda yang terlibat 
dalam proses pembelajaran serta dapat mengambil kesimpulan-kesimpulan yang diharapkan jika diterapkan metode demonstrasi.

Penerapan metode demonstrasi dapat berpengaruh terhadap hasil belajar siswa yang dibuktikan oleh Rohendi et al. (2010) dalam penelitiannya yang berjudul efektivitas metode pembelajaran demonstrasi terhadap peningkatan hasil belajar siswa kelas $\mathrm{X}$ pada mata pelajaran keterampilan komputer dan pengelolaan informasi di sekolah menengah kejuruan dengan rata-rata indeks $N$-Gain sebesar 0,64. Peole et al. (2014) dalam penelitiannya tentang penerapan metode demonstrasi memproleh data hasil belajar pada siklus I dengan presentase daya serap klasikal $71,18 \%$, dan presentase ketuntasan belajar 70,59\%. Hasil belajar pada siklus II mengalami peningkatan dengan presentase daya serap klasikal $85,88 \%$ dan persentase ketuntasan mencapai $100 \%$.

Pembelajaran menggunakan metode demonstrasi juga dapat membantu mengaktifkan siswa dalam kegiatan pembelajaran, terutama dalam hal mengamati sehingga jika model perolehan konsep dikolaborasikan dengan metode demonstrasi maka diharapkan dapat menjadi strategi pembelajaran yang tepat untuk meningkatkan penguasaan konsep siswa dalam pembelajaran fisika. Diluar hal itu, penulis bermaksud untuk memperkenalkan model perolehan konsep dengan metode demonstrasi ke dalam dunia pendidikan untuk dijadikan sebagai alternatif yang dapat membantu dan mempermudah guru dalam menyampaikan pembelajaran fisika.

\section{METODE PENELITIAN}

Jenis penelitian yang digunakan adalah penelitian eksperimen semu dengan desain penelitian pre-test and post-test control group design. Pada penelitian ini dilibatkan tiga variabel yaitu variabel bebas berupa model perolehan konsep dengan metode demonstrasi, variabel terikat berupa penguasaan konsep dan variabel kontrol berupa kemampuan awal siswa kelas eksperimen dan kelas kontrol dianggap sama, guru, materi, tujuan pembelajaran, dan cara penilaian.

Populasi dalam penelitian ini adalah seluruh siswa kelas XI MIPA pada salah satu SMA Negeri yang ada di Lombok Barat tahun pelajaran 2018/2019 yang berjumlah 197 siswa. Teknik pengambilan sampel yang digunakan adalah purposive sampling. Berdasarkan hasil observasi dan kegiatan wawancara yang dilakukan bersama salah seorang guru fisika di sekolah tersebut, sampel yang digunakan adalah siswa kelas XI MIPA 3 dan XI MIPA 6 dengan jumlah siswa masing-masing 25 dan 26 orang.

Instrumen penilaian yang digunakan berupa tes penguasaan konsep. Tes ini menggunakan tes tertulis dalam bentuk tes pilihan ganda sebanyak 30 butir soal. Indikator penguasaan konsep yang digunakan dalam tes ini terdiri dari enam indikator yaitu sebagai berikut: $\mathrm{C} 1$ (mengingat), $\mathrm{C} 2$ (memahami), $\mathrm{C} 3$ (menerapkan), C4 (menganalisa), C5 (mengevaluasi), dan C6 (menciptakan).

Sebelum dilakukan tes, terlebih dahulu instrumen tersebut harus diuji cobakan untuk mengetahui validitas, reliabilitas, daya beda, dan taraf kesukarannya. Berdasarkan hasil uji instrumen, ditetapkan sebanyak 21 soal pilihan ganda sebagai instrumen dalam penelitian karena telah memenuhi 4 kriteria pengujian. Uji analisis data yang digunakan dalam penelitian ini yaitu menggunakan uji$\mathrm{t}$ dengan taraf signifikan $5 \%$ dan derajat kebebasan $\left(n_{1}+n_{2}\right)-2$. Digunakan pula uji $\mathrm{N}$-gain untuk mengetahui peningkatan penguasaan konsep fisika siswa per sub materi pada kelas eksperimen dan kelas kontrol 
Penelitian ini dilakukan dengan memberikan perlakuan pada kelas eksperimen berupa model perolehan konsep dengan metode demonstrasi dan melaksanakan pembelajaran konvensional pada kelas kontrol. Kedua kelas diberikan perlakuan selama tiga kali pertemuan dengan alokasi waktu setiap pertemuan selama 90 menit atau 2 jam pelajaran pada materi alat-alat optik.

\section{HASIL DAN PEMBAHASAN}

Penelitian ini bertujuan untuk untuk menganalisis pengaruh model perolehan konsep dengan metode demonstrasi terhadap penguasaan konsep fisika siswa SMA yang dilakukan pada siswa kelas XI MIPA di salah satu SMA Negeri yang ada di Lombok Barat. Penelitian dilakukan dengan memberikan perlakuan berupa penerapan model perolehan konsep dengan metode demonstrasi pada kelas XI MIPA 3 sebagai kelas eksperimen dan pembelajaran konvensional pada kelas XI MIPA 6 sebagai kelas kontrol. Pengambilan data penelitian dilakukan sebelum dan setelah diberikan perlakuan pada kedua kelas yaitu pada hasil pre-test dan post-test siswa.

Hasil pre-test penguasaan konsep fisika baik pada kelas eksperimen maupun kelas kontrol termasuk dalam kategori rendah. Hal ini terlihat dari nilai rata-rata tes penguasaan konsep masing-masing kelas, yaitu untuk kelas eksperimen adalah 37,3 dan untuk kelas kontrol adalah 35,9 yang jika dibandingkan dengan nilai KKM pada umumnya, rata-rata tersebut dikategorikan tidak tuntas. Hal ini disebabkan karena siswa pada kedua kelas belum diberikan materi pelajaran yang terkait. Untuk meningkatkan penguasaan konsep yang dimiliki oleh siswa, maka diterapkan model prolehan konsep dengan metode demonstrasi pada kelas XI MIPA 3, kemudian menerapkan pembelajaran konvensional pada kelas XI MIPA 6 sebagai pembanding.

Untuk mengukur pengaruh perlakuan yang telah diberikan, kedua kelas diberikan post-test dengan materi, jumlah, dan bobot yang sama dengan soal pre-test. Berdasarkan analisis data post-test, nilai rata-rata kedua kelas sama-sama mengalami peningkatan. Kelas eksperimen memperoleh nilai rata-rata lebih tinggi yaitu 79 dibandingkan dengan nilai rata-rata kelas kontrol yaitu 71. Hasil pre-test dan post-test penguasaan konsep kelas eksperimen dan kelas kontrol dapat dilihat pada Tabel 1.

Tabel 1. Data Hasil Pre-Test dan Post-Test Kelas Eksperimen dan Kelas Kontrol

\begin{tabular}{cccccc}
\hline Tes & Kelas & $\begin{array}{c}\text { Jumlah } \\
\text { Siswa } \\
(\mathrm{N})\end{array}$ & $\begin{array}{c}\text { Nilai } \\
\text { Max. }\end{array}$ & $\begin{array}{c}\text { Nilai } \\
\text { Min. }\end{array}$ & $\begin{array}{c}\text { Rata- } \\
\text { rata }\end{array}$ \\
\hline \multirow{2}{*}{ pre-test } & Eksperimen & 25 & 62 & 14 & 37,5 \\
& Kontrol & 26 & 57 & 10 & 35,9 \\
post-test & Eksperimen & 25 & 90 & 67 & 79 \\
& Kontrol & 26 & 86 & 57 & 71
\end{tabular}

Berdasarkan hasil post-test, kedua kelas sama-sama mengalami peningkatan Jika dibandingkan dengan nilai rata-rata pada pre-test. Sementara untuk mengetahui perbedaan peningkatan yang dialami oleh kedua kelas secara kuantitatif serta pengaruh dari model yang diberikan, maka perlu dilakukan uji hipotesis. Uji hipotesis yang digunakan dalam penelitian ini adalah uji-t karena sampel merupakan kelas yang homogen dengan data yang dihasilkan terdistribusi normal seperti yang terlihat pada Tabel 2. 
Berdasarkan hasil perhitungan uji t, nilai $t_{\text {hitung }}$ yang diperoleh adalah 2,250. Sementara Nilai $t_{\text {tabel }}$ yang ditentukan pada taraf signifikan 5\% adalah 2,012. Oleh karena nilai yang dihasilkan lebih besar dari $\mathrm{t}_{\text {tabel }}$, maka $\mathrm{H}_{0}$ ditolak dan dapat dinyatakan bahwa model perolehan konsep dengan metode demonstrasi berpengaruh terhadap penguasaan konsep fisika siswa.

Tabel 2. Hasil Uji Homogenitas dan Normalitas Kelas Eksperimen dan Kelas Kontrol

\begin{tabular}{|c|c|c|c|c|c|}
\hline \multicolumn{6}{|c|}{ Uji Homogenitas } \\
\hline \multirow{2}{*}{ Kelas } & \multicolumn{2}{|c|}{ Pre-Test } & \multicolumn{2}{|c|}{ Post-test } & \multirow{2}{*}{ Keterangan } \\
\hline & $F_{\text {hitung }}$ & $F_{\text {tabel }}$ & $F_{\text {hitung }}$ & $F_{\text {tabel }}$ & \\
\hline $\begin{array}{c}\text { Eksperimen } \\
\text { Kontrol }\end{array}$ & 1,18 & 1,96 & 1,76 & 1,97 & Homogen \\
\hline \multicolumn{6}{|c|}{ Uji Normalitas } \\
\hline \multirow[b]{2}{*}{ Kelas } & \multicolumn{2}{|c|}{ Pre-Test } & \multicolumn{2}{|c|}{ Post-test } & \\
\hline & $\chi_{\text {hitung }}^{2}$ & $\chi_{\text {tabel }}^{2}$ & $\chi_{\text {hitung }}^{2}$ & $\chi_{\text {tabel }}^{2}$ & Keterangan \\
\hline Eksperimen & 2,231 & 11.070 & 4,247 & 11,070 & Terdistribusi \\
\hline Kontrol & 6,828 & $11,0 / 0$ & 2,520 & $11,0 / 0$ & normal \\
\hline
\end{tabular}

Sebagai tindak lanjut dari analisis data, dilakukan uji N-gain untuk mengetahui peningkatan nilai per sub materi pada kedua kelas. Uji N-Gain berfungsi untuk mengetahui perbedaan signifikan hasil perolehan nilai kelas kontrol dengan kelas eksperimen. Selain itu, Gunawan et al. (2015) mengungkapkan bahwa uji N-Gain dilakukan dalam rangka antisipasi kesalahan penafsiran perolehan skor gain setiap siswa. Adapun hasil yang didapatkan adalah persentase nilai $\mathrm{N}$-gain pada kelas eksperimen selalu lebih besar daripada kelas kontrol. Perolehan nilai rata-rata $\mathrm{N}$-gain pada kelas eksperimen sebesar $67 \%$ dan di kelas kontrol sebesar 55\%, maka dapat disimpulkan bahwa peningkatan penguasaan konsep fisika siswa pada kelas eksperimen lebih baik daripada kelas kontrol. Skor tertinggi pre-test dan post-test baik pada kelas eksperimen maupun kelas kontrol adalah pada sub materi pemantulan cahaya. Untuk sub materi pemantulan cahaya pada kelas eksperimen termasuk dalam kategori tinggi sedangkan untuk sub materi pembiasan cahaya dan alat-alat optik masuk dalam kategori sedang.

Sementara untuk kelas kontrol, keseluruhan materi termasuk dalam kategori sedang. Nilai rata-rata pre-test dan post-test sub materi pemantulan cahaya pada kedua kelas lebih tinggi dari yang lainnya, hal ini disebabkan karena kedalaman dan keluasan materi pada sub materi pemantulan cahaya lebih rendah dibandingkan sub materi pembiasan cahaya dan alat-alat optik, sehingga siswa lebih mudah memahami pelajaran karena penyampaian materi menjadi lebih maksimal. Peningkatan penguasaan konsep fisika siswa per sub materi dapat dilihat pada Tabel 3.

Berdasarkan Tabel 3, terlihat bahwa persentase peningkatan penguasaan konsep fisika siswa kelas eksperimen lebik baik daripada kelas kontrol untuk tiap sub materinya. Peningkatan tersebut dikarenakan adaya perbedaan perlakuan pada kedua kelas yaitu penerapan model perolehan konsep dengan metode demonstrasi pada kelas eksperimen dan pembelajaran konvensional pada kelas kontrol. Penerapan model perolehan konsep dengan metode demonstrasi pada kelas eksperimen berjalan baik serta dapat menambah keaktifan siswa dalam belajar. Hal ini disebabkan karena siswa terlibat langsung selama proses pembelajaran. Pembelajaran dimulai dengan menyajikan contoh positif dan negatif terkait dengan materi yang diajarkan kemudian siswa 
diminta untuk mengamati contoh-contoh tersebut lalu membuat hipotesis sesuai dengan yang diminta oleh peneliti. Tidak hanya aktif dalam hal mengamati, siswa juga dilibatkan secara langsung dalam mendemonstrasikan contoh-contoh benda maupun peristiwa yang terkait dengan materi. Oleh karena hal tersebut, antusiasme siswa dalam mengikuti pelajaran semakin bertambah karena merasa tertarik untuk memperagakan secara langsung hal-hal tertentu di depan kelas.

Tabel 3. Hasil Uji N-Gain Penguasaan Konsep Kelas Eksperimen dan Kelas Kontrol

\begin{tabular}{cccccc}
\hline \multirow{2}{*}{ Kelas } & \multicolumn{3}{c}{$\begin{array}{c}\text { N-Gain Per Sub Materi Penguasaan } \\
\text { Konsep }\end{array}$} & $\begin{array}{c}\text { N- } \\
\text { Gain } \\
\text { Total }\end{array}$ & Kriteria \\
\cline { 2 - 6 } & Pemantulan & Pembiasan & $\begin{array}{c}\text { Alat } \\
\text { Optik }\end{array}$ & & \\
\hline Eksperimen & $71 \%$ & $60 \%$ & $70 \%$ & $67 \%$ & Sedang \\
Kontrol & $62 \%$ & $52 \%$ & $50 \%$ & $55 \%$ & \\
\hline
\end{tabular}

Pada Tabel 3, terlihat bahwa persentase peningkatan penguasaan konsep fisika siswa kelas eksperimen lebik baik daripada kelas kontrol untuk tiap sub materinya. Peningkatan tersebut dikarenakan adaya perbedaan perlakuan pada kedua kelas yaitu penerapan model perolehan konsep dengan metode demonstrasi pada kelas eksperimen dan pembelajaran konvensional pada kelas kontrol. Penerapan model perolehan konsep dengan metode demonstrasi pada kelas eksperimen berjalan baik serta dapat menambah keaktifan siswa dalam belajar. Hal ini disebabkan karena siswa terlibat langsung selama proses pembelajaran. Pembelajaran dimulai dengan menyajikan contoh positif dan negatif terkait dengan materi yang diajarkan kemudian siswa diminta untuk mengamati contoh-contoh tersebut lalu membuat hipotesis sesuai dengan yang diminta oleh peneliti. Tidak hanya aktif dalam hal mengamati, siswa juga dilibatkan secara langsung dalam mendemonstrasikan contoh-contoh benda maupun peristiwa yang terkait dengan materi. Oleh karena hal tersebut, antusiasme siswa dalam mengikuti pelajaran semakin bertambah karena merasa tertarik untuk memperagakan secara langsung hal-hal tertentu di depan kelas.
Sebagaimana yang diungkapkan oleh Nondo et al. (2016) model perolehan konsep merupakan suatu model pembelajaran yang menggunakan data untuk mengajarkan konsep pada siswa dimana guru mengawali pembelajaran dengan menyajikan data atau contoh, kemudian guru meminta siswa untuk mengamati data tersebut. Adapun contoh-contoh yang disediakan oleh peneliti berbeda setiap pertemuan karena harus disesuaikan dengan sub materi yang diajarkan. Contoh pada sub materi pemantulan cahaya adalah cermin, pada sub materi pembiasan cahaya adalah lensa, sementara pada sub materi alat-alat optik adalah lup, mikroskop dan teropong.

Model perolehan konsep dapat berpengaruh baik terhadap proses pembelajaran dikarenakan pada model ini siswa tidak disediakan rumusan suatu konsep, tetapi mereka menemukan konsep tersebut berdasarkan contoh-contoh yang memiliki penekanan-penekanan terhadap ciri dari konsep itu. Penerapan model ini semakin efektif ketika dikolaborasikan dengan metode demonstrasi. Metode demonstrasi digunakan agar siswa menjadi lebih paham terhadap materi yang dijelaskan karena menggunakan alat peraga dan menggunakan media visualisasi yang dapat 
membantu siswa untuk lebih memahami pelajaran.

Hasil ini dapat mendukung beberapa hasil penelitian sebelumnya seperti penelitian yang dilakukan oleh Sa'diyah et al. (2015) tentang model perolehan konsep disertai metode demonstrasi pada pembelajaran IPA-Fisika yang memproleh hasil analisis data dengan nilai sig. sebesar $<0,05$. Selain itu, hasil penelitian yang dilakukan oleh Christiani et al. (2017) mengungkapkan bahwa respon siswa pada materi tekanan zat cair setelah digunakan model perolehan konsep adalah sangat baik. Hal ini ditunjukkan pada hasil angket respon siswa yang telah disebarkan pada 35 siswa kelas VIII-2 di SMP Negeri 5 Sidoarjo bahwa sebanyak $86,39 \%$ menyatakan respon positif terhadap model perolehan konsep.

Hasil penelitian belum maksimal dikarenakan beberapa faktor, diantaranya adalah keterbatasan dalam menyediakan media langsung (benda asli) yang dapat dijangkau oleh selruh siswa.

\section{PENUTUP}

Berdasarkan hasil uji hipotesis, dapat disimpulkan bahwa model perolehan konsep dengan metode demonstrasi berpengaruh positif terhadap penguasaan konsep fisika siswa.

Model perolehan konsep dengan metode demonstrasi ini dapat diterapkan untuk meningkatkan penguasaan konsep fisika siswa dengan memperhatikan beberapa hal, seperti media pembelajaran dan durasi pembelajaran yang disesuaikan dengan kedalaman dan keluasan materi.

\section{REFERENSI}

Arianti, B.I., Sahidu, H., Harjono, A., \& Gunawan. 2016. Pengaruh Model Direct Instruction Berbantuan Simulasi Virtual terhadap Penguasaan Konsep Siswa. Jurnal
Pendidikan Fisika dan Teknologi, 2(4), 159-163.

Christiani, D.E., \& Sudibyo, E. 2017. Penerapan Model Pembelajaran Pemerolehan Konsep untuk Meningkatkan Pemahaman Siswa Kelas VIII pada Materi Tekanan. EJurnal Pensa, 5(3).

Fadilah, S., \& Suyono, S. 2016. Meremediasi Miskonsepsi Siswa Berbasis Gaya Belajar Dimensi Pemahaman pada Konsep Ikatan Kimia Menggunakan Concept Attainmen. UNESA Journal of Chemical Education, 5(2).

Gunawan, Harjono, A., \& Sutrio. 2015. Multimedia Interaktif dalam Pembelajaran Konsep Listrik Bagi Calon Guru. Jurnal Pendidikan Fisika dan Teknologi, 1(1), 9-14.

Kemendikbud. 2013. Permedikbud Nomor 65 Tahun 2013 Tentang Standar Proses. Jakarta: Kemendikbud.

Nondo, F.T., Fihrin, F., \& Ali, M. 2016. Penerapan Model Pembelajaran Pencapaian Konsep untuk Peningkatan Pemahaman Konsep Fisika pada Siswa Kelas X Sma Negeri 8 Palu. Jurnal Pendidikan Fisika Tadulako (JPFT). 4(4).

Oktaviani, D.G., Harjono, A., \& Gunada, I.W. 2018. Penguasaan Konsep Usaha dan Energi Peserta Didik Kelas $\mathrm{X}$ dengan Model Pembelajaran Ekspositori Berbantuan Organizers. Jurnal Pendidikan Fisika dan Teknologi, 4(2), 192-201.

Peole, A.E., Agustina, V.M., \& Alibasyah, L. 2014. Meningkatkan Hasil Belajar Melalui Metode Demonstrasi pada Pembelajaran IPA di Kelas V SDN Taopa Kabupaten Parigi Moutong. Jurnal Kreatif Tadulako, 4(7).

Rohendi, D., Ginanjar, M.A., \& Sutarno, H. 2010. Efektivitas Metode Pembelajaran Demonstrasi terhadap Peningkatan Hasil Belajar 
Siswa Kelas X pada Mata Pelajaran

Keterampilan Komputer dan

Pengelolaan Informasi di Sekolah

Menengah Kejuruan. Jurnal

Pendidikan Teknologi Informasi dan Komunikasi, 3(1), 16-18.

Sa'diyah, H., Indrawati, I., \& Handayani, R.D. 2015. Model Pembelajaran Concept Attainment disertai Metode Demonstrasi pada Pembelajaran IPA-Fisika di SMP (Studi Eksperimen pada Aktivitas dan Hasil Belajar IPA-Fisika). Jurnal Pembelajaran Fisika, 4(3).

Sugiono, S. 2002. Metode Penelitian Administrasi RdD. Bandung: Alfabeta.

Syaiful, B.D., \& Zain, A. 2006. Strategi Belajar Mengajar. Jakarta: Rineka Cipta.

Tuqalby, R., Sutrio,S., \& Gunawan, G. 2017. Pengaruh Strategi Konflik Kognitif terhadap Penguasaan Konsep pada Materi Fluida Siswa Sman 3 Mataram Tahun Ajaran 2016/2017. Jurnal Pendidikan Fisika dan Teknologi, 3(1), 8-13.

Yahya, I.B.L., Prihandono, T., \& Supriadi, B. 2017. Penerapan Model Concept Attainment disertai Teknik Concept Mapping dalam Pembelajaran Fisika di MA. Jurnal Pembelajaran Fisika, 6(1), 63-67.

Yulianci, S., Gunawan, G., \& Doyan, A. 2017. Model Inkuiri Terbimbing Berbantuan Multimedia Interaktif untuk Meningkatkan Penguasaan Konsep Fisika Peserta Didik. Jurnal Pendidikan Fisika dan Teknologi, 3(2), 146-154. 